\title{
Nutrients Removal Efficiency Assessment of Constructed Wetland for the Rural Domestic Wastewater Growing Distinct Species of Vegetation
}

Ittehad Hussain ${ }^{1}$, Xiwu Lu ${ }^{1^{*}}$, Javid Hussain ${ }^{2}$, Raana Fahim ${ }^{1}$ and Stanislaus Tombe Venusto Lako

${ }^{1}$ School of Energy and Environment, Department of Environmental Science and Engineering, Southeast University, Nanjing 210096, PR China

${ }^{2}$ Department of Environmental Sciences, Balochistan University of Information Technology, Engineering and Management Sciences, Quetta, Pakistan

"Corresponding author: Xiwu Lu, School of Energy and Environment, Department of Environmental Science and Engineering, Southeast University, Nanjing 210096, PR China, Tel: +862583793022; E-mail: xiwulu@seu.edu.cn

Received: October 08, 2018; Accepted: October 18, 2018; Published: October 25, 2018

Copyright: (C) 2018 Hussain I, et al. This is an open-access article distributed under the terms of the Creative Commons Attribution License, which permits unrestricted use, distribution, and reproduction in any medium, provided the original author and source are credited.

\begin{abstract}
In this study, the performance of horizontal subsurface flow constructed wetland for the nutrients removal in rural domestic wastewater using different vegetation plants has been assessed with hydraulic loading rate $0.2 \mathrm{~m} \cdot \mathrm{d}^{-1}$ and hydraulic retention time $1.25 \mathrm{~d}$. The system was built and operated for twelve weeks as a tertiary treatment after biological processes to improve the quality of effluents of rural sewage. Three different vegetation species i.e., Mustard, Celery and Watercress were selected and grown in the wetlands. The system exhibited high pollutants removal efficiencies as Mustard achieving 76.53\%, 90.18\%, 79.89\%, 93.14\% and 70.77\% for $\mathrm{TN}^{\mathrm{N}}, \mathrm{NO}_{3}{ }^{-} \mathrm{N}, \mathrm{TP}^{-}, \mathrm{NH}_{4}{ }^{-} \mathrm{N}$ and TSS, while Celery showed $71.73 \%, 90.18 \%, 71.95 \%, 77.15 \%$ and $75.39 \%$ and Watercress presented removal efficiency as $73.41 \%, 93.64 \%, 80.95 \%, 86.69 \%$ and $81.91 \%$, respectively. The concentrations of pollutants in all effluents of three different plants were lower than the Class $1 \mathrm{~A}$ regulated values recommended by Chinese National Standards GB18918-2002. Horizontal subsurface flow constructed wetlands planted with Mustard, Celery and Watercress is a reasonable alternative method for the treatment of rural domestic wastewater.
\end{abstract}

Keywords: Nutrients removal; Vegetation species; Rural domestic wastewater; HSSF-CWs; Cost-efficient

\section{Highlights}

- Three different vegetation species i.e., Mustard, Celery and Watercress were selected and grown in the wetlands.

- The influent and effluent concentrations of total nitrogen (TN), total nitrate $\left(\mathrm{NO}_{3}{ }^{-} \mathrm{N}\right)$, total phosphorous $(\mathrm{TP})$, ammonium $\left(\mathrm{NH}_{4}\right.$ $\mathrm{N}$ ) and total suspended solids (TSS) were analyzed and measured.

- The system exhibited high pollutants removal efficiencies.

- The concentrations of pollutants in all effluents of three different plants were lower than the Class $1 \mathrm{~A}$ regulated values recommended by Chinese National Standards GB18918-2002.

\section{Introduction}

Water is an essential environmental factor to maintain the food supply and productive environment for the survival of human beings and other living organisms. Rapidly growing human population and economies have soared the demands of freshwater [1], Wastewater in developing countries is released to water bodies and aquatic habitants improperly and untreated that has resulted in devastating impacts on environment and human health [2], Many regions of the world are already facing water crisis, with about one billion people without having inadequate fresh and drinking water. In addition, more than $90 \%$ of infectious diseases in developing countries are caused and transmitted to human beings through polluted water [1]. The main sources of polluting water can be residential, commercial, industrial and agricultural activities. Wastewater must be treated to overcome its adverse effect on public health and ecosystem [3]. In developing countries, conventional treatment of wastewater may not be applicable for its costly expenses and installation. Therefore, reasonable and environment-friendly methods are needed for the treatment of wastewater [4]. Constructed wetlands have been significantly used since last years as an alternative method and considered as an appropriate technology for the treatment of waste water in small communities [5]. CWs are artificially designed systems consisting of medium like soil, sand and gravels and planted by plants tolerant to saturated environmental conditions [6], which offer efficient and attractive pollutants removal efficiency through physical, chemical, and biological mechanisms. Many of contaminants such as pathogens, organic materials, nutrients, and toxic heavy metals can be removed and minimized with the help of Constructed wetlands through filtration, sedimentation, coagulation, adsorption, plant uptakes and microbial transformation.

In Horizontal subsurface flow constructed wetlands (HFCWs), nutrients and organic matter are removed by aerobic bacteria attached to plant roots and porous media. Therefore, wetland plants have vital and effective role in the purification of wastewater [7]. The main objective of this study was aimed to improve constructed wetland system to overcome the pollution indicators (total nitrogen, total phosphorous, nitrate, ammonium nitrogen and total suspended solids and to experience the improvement of productive environment and economic growth of vegetations.

\section{Materials and Methods}

\section{Experimental setup and design of HSF CW}

The horizontal subsurface flow constructed wetland system was designed and operated at the Campus of Southeast University, New District, Wuxi city, Jiangsu province, P.R China, consisting total area $100 \mathrm{~m}^{2}$. The region has four distinct seasons having humid monsoon 
Citation: Hussain I, Lu X, Hussain J, Fahim R, Lako STV (2018) Nutrients Removal Efficiency Assessment of Constructed Wetland for the Rural Domestic Wastewater Growing Distinct Species of Vegetation. J Environ Anal Toxicol 8: 588. doi:10.4172/2161-0525.1000588

Page 2 of 6

climate with ample rainfall and sunshine. The average annual temperature over last three decades (since 1982) is $16^{\circ} \mathrm{C}$ with 123 rainy days and average precipitation is $1121.7 \mathrm{~mm}$ [8]. Horizontal subsurface flow constructed wetland was established for the experimental work and the size of each bed was $2.5 \mathrm{~m} \times 0.3 \mathrm{~m} \times 0.5 \mathrm{~m}$ (length $\times$ width $\times$ height), made of concrete and lined with epoxy coatings. Each bed was packed with a supporting layer of $10 \mathrm{~cm}$ course Gravels, 5-10 cm clay, $10 \mathrm{~cm}$ small gravels and $5-10 \mathrm{~cm}$ cermasite stones (Figure 1). The wastewater was entered from distribution channel connected to wastewater tank with controlled flow. Three different species of vegetation plants were selected (Table 1). and grown in constructed wetland and selection was made on their easy availability in market and ability to climatic adaption. All beds were inspected on daily basis to avoid any obstruction in flow especially in inlet and outlet pipes that may be caused by suspended solids presented in wastewater. Panoramic view and plants' growth conditions in HSF CWs during study duration are shown in Figure 1.

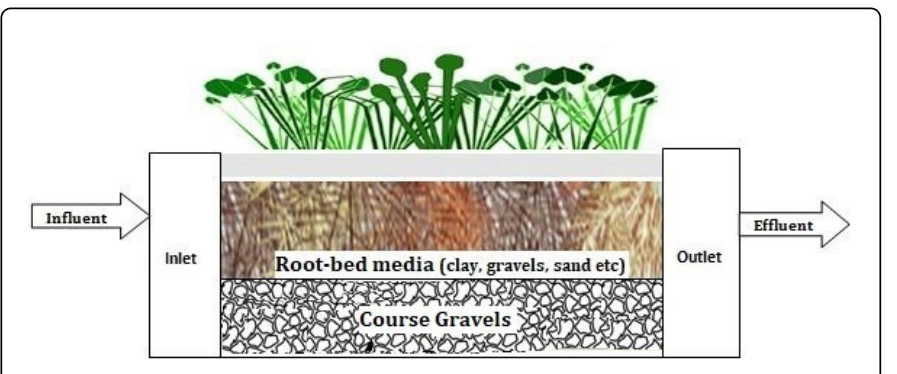

Figure 1: Schematic diagram of HSF CWs and conditions of plants during experimental duration.

\section{Setup operation and sampling}

Wastewater from the residential area, restaurants and student's dormitories in premises of Southeast University, Wuxi Campus was allowed to enter into wetland system after primary treatment. Three different beds were constructed, and each bed was planted with random vegetation plants as Brassica, Apium and Nasturtium (Table 1). Water samples were collected from inlet and outlet of the wetland beds in plastic bottles on weekly basis for evaluation performance and experimental work. Characteristics of wastewater are presented in Table 2.

\begin{tabular}{|l|l|l|l|}
\hline S. No. & Plant Name & Scientific Name & Used Name \\
\hline 1 & Mustard & Brassica & Brassica \\
\hline 2 & Celery & Apium graveolens & Apium \\
\hline 3 & Watercress & Nasturtium officinale & Nasturtium \\
\hline
\end{tabular}

Table 1: Selected vegetation plants for experimental work.

\section{Determination methods}

Standard methods recommended by US Environmental Protection Agency (US EPA) were used for the determination of Nitrate $\left(\mathrm{NO}_{3}{ }^{-} \mathrm{N}\right)$, Total Nitrogen (TN), Total Phosphorous (TP), Ammonium (NH-N) and Total Suspended Solids (TSS) [9]. The following equation was used to calculate the TSS in water sample $(\mathrm{mg} / \mathrm{l})$.

$\mathrm{TSS}(\mathrm{mg} / \mathrm{l})=((\mathrm{A}-\mathrm{B}) \times 1000) / \mathrm{V}$

Where, A represent dried weight of residue and filter paper,

$\mathrm{B}=$ Weight of filter paper,

$\mathrm{V}=$ Wastewater sample used.

Whereas, Dissolved Oxygen and $\mathrm{pH}$ were measured by using DO Meter (DO200) and pH Meter (pH100) YSI, respectively.

\section{Statistical analysis}

Microsoft Excel (MS Office package-10) and Origin 9 (Origin Lab Corporation) were used for data analysis and nutrients removal variances.

\section{Results and Discussion}

Average experimental data for this study is shown in (Tables 2 and 3) for both inlets and outlets of three species of vegetations i.e., Mustard, Celery and Watercress. Almost all three species of plants offered significant increase in removal efficiencies for TN. Concentrations of $\mathrm{TN}$ were $76.53 \%, 71.73 \% 73.41 \%$ (Figures $2-4$ ), whereas $79.89 \%, 71.95,80.95 \%$ for TP (Figure 3). The efficiency for $\mathrm{NO}_{3}{ }^{-} \mathrm{N}$ and $\mathrm{NH}_{4}{ }^{-} \mathrm{N}$ achieved by Mustard, Celery and Watercress was $79.89 \%, 71.95 \%, 80.95 \%$ and $93.14 \%, 77.15 \%, 86.69 \%$, respectively (Figures 5 and 6), while the removal efficiency for TSS by all these three species of plants i.e., Mustard, Celery and Watercress was $70.77 \%$, $75.39 \%$ and $81.94 \%$, respectively (Figure 6). 
Citation: Hussain I, Lu X, Hussain J, Fahim R, Lako STV (2018) Nutrients Removal Efficiency Assessment of Constructed Wetland for the Rural Domestic Wastewater Growing Distinct Species of Vegetation. J Environ Anal Toxicol 8: 588. doi:10.4172/2161-0525.1000588

Page 3 of 6

\begin{tabular}{|c|c|c|c|c|c|}
\hline Operational time (weeks) & $\mathrm{TN}(\mathrm{mg} / \mathrm{l})$ & $\mathrm{TP}(\mathrm{mg} / \mathrm{l})$ & $\mathrm{NO}_{3}-\mathrm{N}(\mathrm{mg} / \mathrm{l})$ & $\mathrm{NH}_{4}-\mathrm{N}(\mathrm{mg} / \mathrm{l})$ & TSS (mg/l) \\
\hline 1 & 31.06 & 1.73 & 16.37 & 16.78 & 18 \\
\hline 2 & 25.24 & 1.39 & 13.26 & 17.34 & 12 \\
\hline 3 & 41.56 & 1.68 & 24.19 & 15.17 & 16 \\
\hline 4 & 46.22 & 1.65 & 26.43 & 21.17 & 18 \\
\hline 5 & 43.37 & 1.72 & 24.65 & 19.84 & 13 \\
\hline 6 & 44.78 & 2.06 & 26.43 & 18.51 & 16 \\
\hline 7 & 45 & 1.83 & 26.45 & 19.95 & 14 \\
\hline 8 & 47.45 & 2.29 & 25.12 & 22.51 & 15 \\
\hline 9 & 49.65 & 2.17 & 26.76 & 23.18 & 9 \\
\hline 10 & 43.11 & 1.94 & 25.81 & 18.75 & 45 \\
\hline 11 & 47.05 & 2.19 & 28.28 & 19.01 & 64 \\
\hline 12 & 49.15 & 2.04 & 27.08 & 20.51 & 20 \\
\hline Average & 45.29 & 2.03 & 25.84 & 21 & 23 \\
\hline
\end{tabular}

Table 2: Raw sewage characteristics during experimental duration at temperature 7.1 to $21.4^{\circ} \mathrm{C}$.

\begin{tabular}{|l|l|l|l|l|l|l|l|l|l|}
\hline & \multicolumn{3}{|l}{ Mustard } & \multicolumn{3}{l}{ Celery } & \multicolumn{2}{l|}{ Watercress } \\
\cline { 2 - 11 } & Min & Max & Mean \pm SD & Min & Max & Mean \pm SD & Min & Max & Mean \pm SD \\
\hline TN & 3.1 & 8.71 & $6.17 \pm 0.2625$ & 7.43 & 11.92 & $7.43 \pm 0.1720$ & 10.09 & 0.57 & $6.99 \pm 0.1235$ \\
\hline $\mathrm{NO}_{3}-\mathrm{N}$ & 0.17 & 0.50 & $0.36 \pm 0.123$ & 0.31 & 6.24 & $2.58 \pm 2.0483$ & 0.09 & 2.68 & $1.20 \pm 0.9244$ \\
\hline $\mathrm{NH}_{4}-\mathrm{N}$ & 1.52 & 6.64 & $4.34 \pm 1.5283$ & 0.69 & 3.50 & $7.20 \pm 1.0107$ & 0.22 & 5.06 & $2.12 \pm 1.2986$ \\
\hline TP & 0.09 & 0.57 & $0.45 \pm 0.1235$ & 0.23 & 0.78 & $0.50 \pm 0.1964$ & 0.16 & 4.61 & $0.36 \pm 1.5095$ \\
\hline TSS & 1.00 & 7.00 & $6.33 \pm 2.0226$ & 2.00 & 9.00 & $5.33 \pm 2.7747$ & 1.00 & 7.00 & $3.91 \pm 1.7494$ \\
\hline
\end{tabular}

Table 3: Average values of effluents of the three different plants in HSFCW. 
Citation: Hussain I, Lu X, Hussain J, Fahim R, Lako STV (2018) Nutrients Removal Efficiency Assessment of Constructed Wetland for the Rural

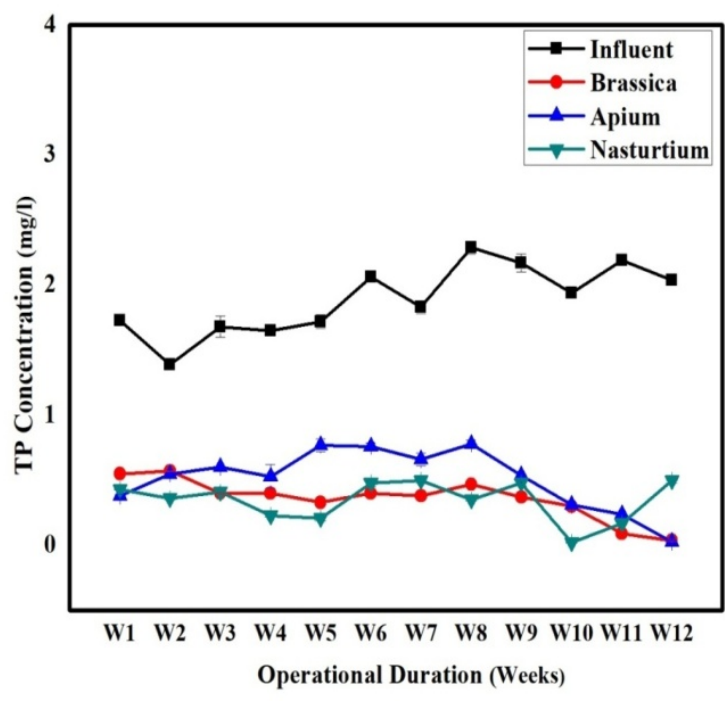

Figure 2: TP concentrations during twelve weeks of experimental durations.

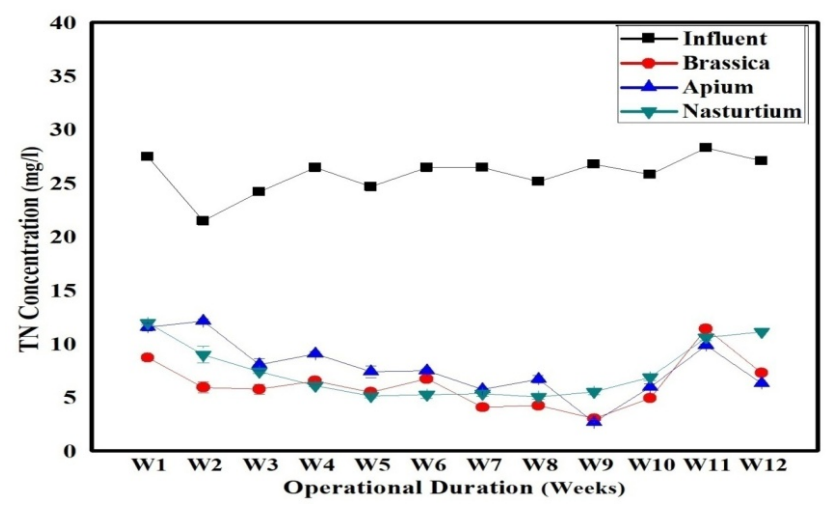

Figure 3: TN concentrations during twelve weeks of experimental durations.

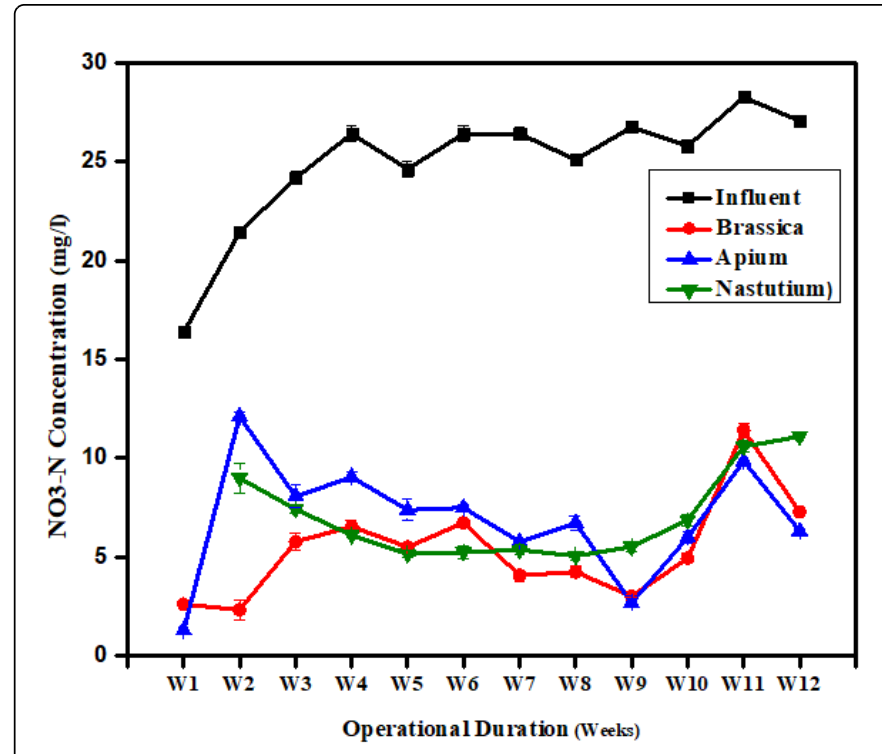

Figure 4: $\mathrm{NO}^{-} \mathrm{N}$ concentration during 12 weeks of experimental durations.

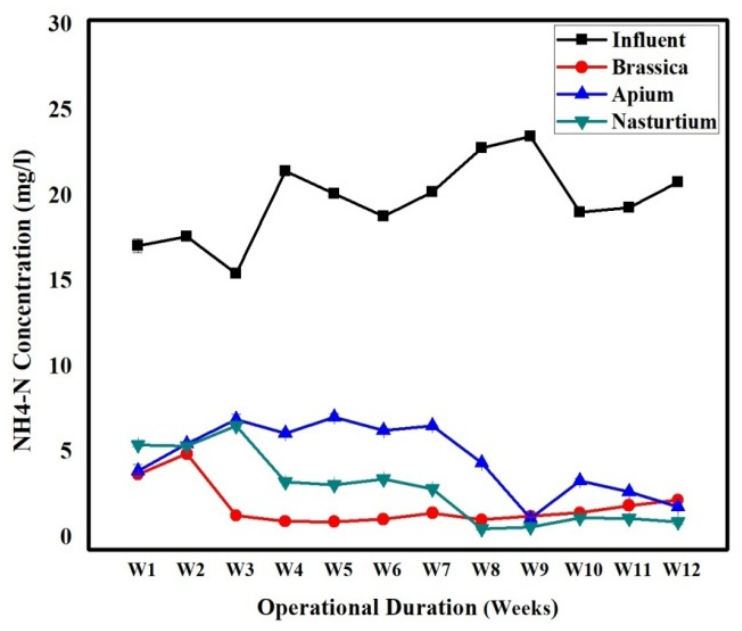

Figure 5: $\mathrm{NH}_{4}{ }^{-} \mathrm{N}$ concentration during 12 weeks of experimental durations. 
Page 5 of 6

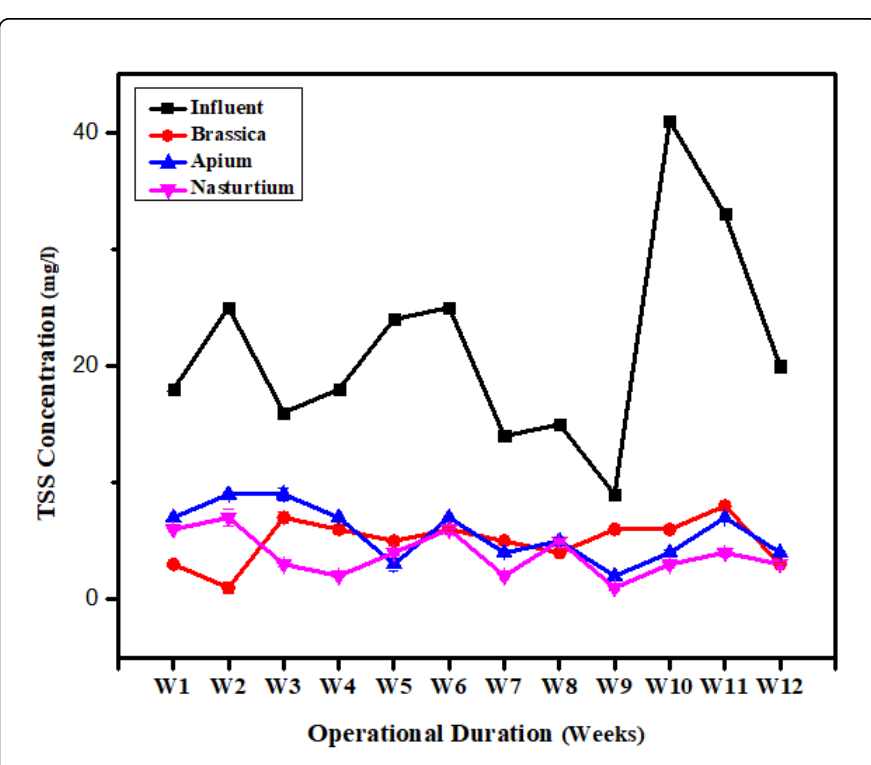

Figure 6: TSS concentration during 12 weeks of experimental durations.

Nutrients have great and significant role in affecting plants growth in constructed wetland systems [10]. For the most favorable growth and uptake, each species of plant needs different amount of nutrients [11]. The efficiency assessment of horizontal subsurface flow constructed wetland was evaluated for twelve weeks under variable temperature ranging from 7.1 to $21.4^{\circ} \mathrm{C}$. All three plants grew well when added with a mixture of $\mathrm{NO}_{3}{ }^{-} \mathrm{N}$ and $\mathrm{NH}_{4}{ }^{-} \mathrm{N}$ [12]. Brassica, $A$. graveolens and $N$. officinale were green, fresh, healthy and grew well in all beds under $\mathrm{NO}_{3}{ }^{-} \mathrm{N} / \mathrm{NH}_{4}{ }^{-} \mathrm{N}$ ratio of $1: 1$, and increasing amounts of $\mathrm{NO}_{3}{ }^{-} \mathrm{N}$ subdued growth [13].

In constructed wetlands, nitrogen removal is occurred due the absorptions by the substrate, nitrification, volatilization and plant uptake [14]. Many researchers has observed, that mostly amount of $\mathrm{NH}_{4}{ }^{-} \mathrm{N}$ removal is occurred by microbial action sand little amount is removed through plant absorption in constructed wetlands [15], whereas most of the $\mathrm{NH}_{4}{ }^{-} \mathrm{N}$ is removed by volatilization on higher $\mathrm{pH}$ [16]. The processes of nitrification are affected by inorganic carbon source, alkalinity, dissolved oxygen, temperature, $\mathrm{pH}$ and $\mathrm{NH}_{4}{ }^{-\mathrm{N}}$ concentration [17]. $\mathrm{NH}^{-} \mathrm{N}$ uptake consumes high amount of oxygen than $\mathrm{NO}_{3}{ }^{-} \mathrm{N}$. Ammonium breakdown takes place in the roots and sugar is delivered from leaves to roots after reaction, whereas $\mathrm{NO}_{3}{ }^{-} \mathrm{N}$ is conveyed to leaves and reduces to ammonium after it reacts with sugar [18]. Plants consumes more sugar at high respiration leaving less for $\mathrm{NH}_{4}{ }^{-} \mathrm{N}$ metabolism. Brassica, Apium greveleons and Nasturtium officinale in horizontal subsurface flow constructed wetland grew with well root system and strong oxygen transferring capabilities providing good aerobic environment around the root systems that prefer nitrifying bacteria and exceed $\mathrm{NH}_{4}{ }^{-} \mathrm{N}$ removal abilities. Roots and Rhizomes below the ground are critical for the nitrogen removal from wastewater. They provide nutrients and exudates to fuel the microorganisms [19]. Plant root system is a vital parameter to consider before choosing plants for constructed wetlands, because bigger root system can get up much amount of nutrients and thus increase the removal of nutrients.

\section{Conclusion}

The recent study presented the effect of three different vegetation plants and media substrate in horizontal subsurface flow constructed wetland for the removal of pollutants in rural domestic wastewater using horizontal subsurface flow constructed wetland. For different reasons, Brassica, Apium greveleons and Nasturtium officinale are efficient to get optimum nutrients (TN, TP, $\mathrm{NO}_{3} \mathrm{~N}, \mathrm{NH}_{4}{ }^{-} \mathrm{N}$ and TSS) removal under a variable temperature ranging from $7.1^{\circ} \mathrm{C}$ to $21.5^{\circ} \mathrm{C}$ using same media substrate. Almost all plants presented very high removal efficiencies as $76.53 \%, 90.18 \%, 79.89 \%, 93.14 \%$ and $70.77 \%$ for $\mathrm{TN}, \mathrm{NO}_{3}-\mathrm{N}, \mathrm{TP}, \mathrm{NH}_{4}{ }^{-} \mathrm{N}$ and $\mathrm{TSS}$, while Celery showed $71.73 \%$, $90.18 \%, 71.95 \%, 77.15 \%$ and $75.39 \%$ and removal efficiency for watercress was $73.41 \%, 93.64 \%, 80.95 \%, 86.69 \%$ and $81.91 \%$, respectively. This study suggests its implementation to reduce the gap between food supplies and water needs and this will also boost the applications of constructed wetlands for the productive environment.

\section{Acknowledgements}

Our gratitude goes to Ministry of Environment, People Republic of China for its support, permitting this study and equipping laboratory facilities. This research was financially supported by National Science and Technology Major Project No. 2017ZX07202004.

\section{References}

1. Pimentel D (2004) Agricultural and Environmental Issues. Water Resources 54: 10.

2. Massoud MA, Tarhini A, Nasr JA (2009) Decentralized approaches to wastewater treatment and management: Applicability in developing countries. Journal of Environmental Management 90: 652-659.

3. Rono AK (2017) Evaluation of TSS, BOD5, and TP in Sewage Effluent Receiving Sambul River. Pollution Effects and Control, p: 5.

4. Abbasi HN, Vasileva V, Lu X (2017) The Influence of the Ratio of Nitrate to Ammonium Nitrogen on Nitrogen Removal in the Economical Growth of Vegetation in Hybrid Constructed Wetlands. Environments 4: 24.

5. Álvarez JA, Ruíz I, Soto M (2008) Anaerobic digesters as a pretreatment for constructed wetlands. Ecological Engineering 33: 54-67.

6. US Environmental Protection Agency (2000) Constructed wetlands treatment of municipal wastewaters, USEPA.

7. Fu WJ, Tang Y (2005) The roles of plants in constructed wetlands and species selection. Sichuan Environment, p: 45.

8. Zhai YM, Hou MM, Shao XH, Yang Q (2016) The comprehensive effects of the subsurface drainage on greenhouse saline soil, tomato yield and quality. Advance Journal of Food Science and Technology 10: 691-694.

9. American Public Health Association (1989) American Water Works Association. Standard methods for the examination of water and wastewater. American Public Health Association, Washington DC, USA.

10. Petrucio MM, Esteves FA (2000) Uptake rates of nitrogen and phosphorus in the water by Eichhornia crassipes and Salvinia auriculata. Revista Brasileira de Biologia 60: 229-236.

11. Santamaria P, Elia A, Parente A, Serio F (1998) Fertilization strategies for lowering nitrate content in leafy vegetables: chicory and rocket salad cases. Journal of Plant Nutrition 21: 1791-1803.

12. Mengel K, Kirkby EA, Kosegarten, H, Appel TT (2001) Nitrogen in Principles of Plant Nutrition, pp: 397-343.

13. Li J, Zhou JM, Duan ZQ (2007) Effects of elevated CO2 concentration on growth and water usage of tomato seedlings under different ammonium/ nitrate ratios. Journal of Environmental Sciences 19: 1100-1107.

14. Vymazal J (2007) Removal of nutrients in various types of constructed wetlands. Science of the Total Environment 380: 48-65.

15. Lv T, Zhang Y, Carvalho PN, Zhang L, Button M, et al. (2017) Microbial community metabolic function in constructed wetland mesocosms 
Citation: Hussain I, Lu X, Hussain J, Fahim R, Lako STV (2018) Nutrients Removal Efficiency Assessment of Constructed Wetland for the Rural Domestic Wastewater Growing Distinct Species of Vegetation. J Environ Anal Toxicol 8: 588. doi:10.4172/2161-0525.1000588

Page 6 of 6

treating the pesticides imazalil and tebuconazole. Ecological Engineering 98: 378-387.

16. Picot B, El Halouani H, Casellas C, Moersidik S, Bontoux J (1991) Nutrient removal by high rate pond system in a Mediterranean climate (France). Water Science and Technology 23: 1535-1541.

17. Lee CG, Fletcher TD, Sun G (2009) Nitrogen removal in constructed wetland systems. Eng Life Sci 9: 11-22.
18. Devaux C, Baldet P, Joubes J, Dieuaide Noubhani M, Just D, et al. (2003) Physiological, biochemical and molecular analysis of sugar-starvation responses in tomato roots. Journal of Experimental Botany 54: 1143-1151.

19. Stottmeister U, Wießner A, Kuschk P, Kappelmeyer U, Kästner M, et al (2003) Effects of plants and microorganisms in constructed wetlands for wastewater treatment. Biotechnology Advances 22: 93-117. 